\title{
Friction and Endurance of Prelubricated and Unlubricated Ball Bearings at High Speeds and Extreme Temperatures
}

\author{
Hobart S. White
}

(April 23, 1959)

\begin{abstract}
Endurance tests were made with 20 -millimeter bore prelubricated ball bearings, at 10,000 revolutions per minute, using polyester felt rings saturated with di(2-ethylhexyl) sebacate containing appropriate additives, at ambient temperatures ranging from $80^{\circ}$ to $400^{\circ} \mathrm{F}$. Tests were made with greases for comparative purposes. Results indicate that endurance with these oil-soaked pads is comparable with the high-temperature performance of MIL-G-3278 [1] ${ }^{1}$ grease at $250^{\circ} \mathrm{F}$ and MIL-L-3545 [2] grease at $300^{\circ} \mathrm{F}$. Some endurance tests were made with special bearings (20-millimeter bore) made of high-speed tool steel, prelubricated at $450^{\circ} \mathrm{F}$ ambient temperature, and unlubricated at $650^{\circ} \mathrm{F}$ ambient temperature $\left(5,000\right.$ revolutions per minute at $\left.650^{\circ} \mathrm{F}\right)$. Experiments were made with greased bearings and with felt-pad oiled bearings in gyros and small high-speed direct-current motors at high temperatures. With oiled bearings and with unlubricated bearings, wearing or breaking of separators (ball cages) was the most common cause of failure. Compared to low-temperature greases MIL-G-3278 [1] and MIL-G-7421 [3], with oiled bearings starting friction was low and running friction was about one-tenth that of greased bearings at $-75^{\circ} \mathrm{F}$ ambient temperature.
\end{abstract}

\section{Introduction}

In aircraft accessory equipment, such as gyros, motors, and inverters, it is highly desirable that the ball bearings be prelubricated in such a manner that no further lubrication is required during their useful life. At ordinary temperatures, ball bearings prepacked with suitable greases may be operated several thousand hours satisfactorily. However, accessory equipment in modern aircraft is subjected to temperatures ranging from $-65^{\circ}$ to $+300^{\circ} \mathrm{F}$, and in some cases to $450^{\circ} \mathrm{F}$ or higher. In many such applications, conventional and even special greases are not satisfactory because of excessive friction at low temperatures and short endurance life at high temperature.

One of the chief difficulties with greases has been that the soaps or other thickeners cause high friction at low temperatures and are not chemically stable at high temperatures. Although much progress has been made in the development of greases suitable for prelubrication at high temperatures, not much progress has been made in developing a grease suitable for use at both extremes of temperature. Some previous work [4] at the National Bureau of Standards indicated that instead of thickeners as used in greases, a feltlike material could be used to hold a supply of suitable oil and bleed it slowly to the races of the ball bearings.

The wool felt used in the previous work charred badly at $325^{\circ} \mathrm{F}$. More recently, synthetic felts which will withstand much higher temperatures than wool felt have become available. Accordingly, further work (sponsored by the Bureau of Aeronautics, Department of the Navy) was started in December of 1955 , with polyester felt rings incorporated in size $204 \mathrm{~K}$ ball bearings which have a

1 Figures in brackets indicate the literature references at the end of this paper. nominal width of 0.8125 in. instead of the more conventional width of $0.5512 \mathrm{in}$.

The main objective of this work was to investigate the performance with the oil-soaked felt-pad method of prelubrication for comparison with grease prelubrication in high-speed applications requiring low friction at low temperatures and long-endurance life at high temperatures. However, some experiments were made with unlubricated bearings.

\section{Apparatus}

\subsection{Endurance Test Machines}

Four machines were built for making endurance tests at high temperatures. Each shaft and housing was made to accommodate $20-\mathrm{mm}$ bore test bearings having a nominal width of 0.8125 in. (such as Fafnir 204K'T ), and provided with spacers such that the more conventional size $204 \mathrm{~K}$ (SAE No. $20 \mathrm{BC} 02$ ) having a nominal width of $0.5512 \mathrm{in}$. could be tested also. The test bearing is mounted outboard on a steel spindle which is supported by two self-alining oil-lubricated pillow block ball bearings with $1 \frac{3}{16}$-in. bores. Test bearing seats on the shafts were made $0.7872 \mathrm{in} . \pm 0.0002 \mathrm{in}$. in diam and the housing bores were made 1.8504 in. \pm 0.0002 in. A nut is used to secure the inner race to each shaft, and removable plates which act as bearing shields are used on each end of the housing to secure the outer race.

A compression spring is used to apply a 5-lb axial load, and a weight at the lower end of a torque arm attached to the bearing housing adds to the weight of the housing to provide a 3-1b radial load. A leaf-actuated microswitch is located under the base of each machine such that a torque of about 3,000 g-cm causes the torque arm to operate the microswitch which adds a $600-\mathrm{w}$ heater load on the motor 
circuit and causes quick operation of the overload breaker in each motor circuit.

Two electric heaters in series are mounted below the bearing housing. The heaters and bearing housing assembly are enclosed in an aluminum alloy chamber. Figure 1 shows a machine with the chamber in place and another with the chamber removed. The temperature is controlled by a bimetallic regulator, and measured by a thermocouple almost contacting the outer race of the test bearing and another in the air near the bearing housing. The thermocouples are electrically insulated to avoid interconnection and pickup of small stray voltages.

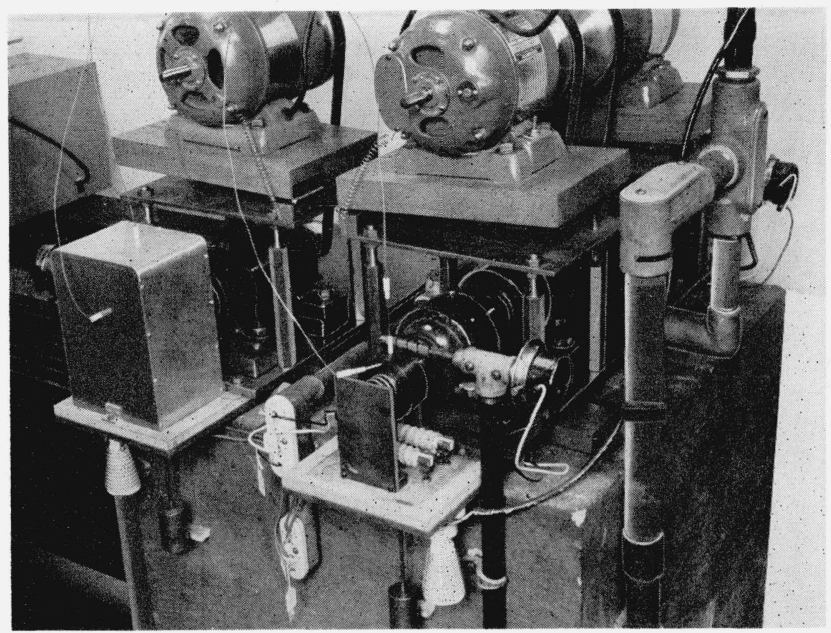

FIGURE 1. High-temperature ball bearing endurance testing machines.

For operation at $10,000 \mathrm{rpm}$, each spindle is driven by a $1 / 2-\mathrm{hp}, 3,450-\mathrm{rpm}, 115-\mathrm{v}$, capacitor-type motor through a 1-in. wide flat fabric belt, with a 2 -in. diam pulley on the spindle and a $57 / 8$-in. diam pulley on the motor. The pillow block ball bearings supporting each spindle are lubricated with a MIL-L 7808 type of synthetic oil containing a viscosity index improver and a rust inhibitor.

\subsection{Friction Test Machine}

The test shaft for the friction testing machine is similar to the endurance test shafts except that it is longer to allow for the outboard portion to extend through the wall of an insulated box. The shaft and test-bearing housing were made of type 303 stainless steel, to prevent rusting from condensation which occurs after low-temperature tests. A cast iron ring fitted around the housing provides additional load. A pendulum consists of an aluminum alloy tube, a small bob, and a pointer which measures displacement from the zero line on a horizontal scale. The test-bearing-housing assembly is mounted in an insulated box, which has an internal compartment containing a blower and space for dry ice. The front is removable, and has an observation window. Either of two brass weights can be placed on the bob for higher ranges of torque. The pendulum was calibrated with the bob and with each of the brass weights in place, so that three ranges of torque capacity are available. The load on the bearing is in the range from 3.6 to $4.3 \mathrm{lb}$, depending on the use of the brass weights for the desired torque range. Since the torque to be investigated is mostly that resulting from shearing of the lubricant, this variation in loading is not considered important. The lower end of the pendulum tubing dips into a damping fluid in an open pan back of the scale, for minimizing fluctuations. The test spindle may be driven at speeds ranging from 10 to $10,000 \mathrm{rpm}$, by motorized drives back of the insulated box.

\subsection{Miscellaneous Apparatus}

A modified air-driven gyro and a preheating coil for the compressed air were mounted in a conventional laboratory oven. The modified gyro is similar to those tried by a Coordinating Research Council Sub-Panel for testing lubricants in miniature ball bearings at 20,000 rpm at high temperature.

Several small motors, 26-v, d-c, 11,000 rpm, $1 / 20$-hp, were used for testing prelubricated instrument bearings. A 26-v, d-c, 11,000-rpm, 1/12-hp motor was modified to act as a generator to load the above motors in some tests.

\section{Materials}

\subsection{Test Bearings}

Ball bearings which were used in the tests on the endurance machines and on the friction machine included the conventional size $204 \mathrm{~K}$ (20-mm bore, 0.5512 -in. width) and the extra wide size $204 \mathrm{~K}$ T'T (0.8125-in. width), having rings and balls made of SAE No. 52100 steel (or possibly SAE No. 51100 in some cases for the balls), with pressed steel separators.

Special bearings made of high-speed tool steel were used for tests at temperatures above $400^{\circ} \mathrm{F}$. Some of these, including the separators, were made of AISI type M-2 tool steel, and a few were made of type $M-10$ steel with silver-plated beryllium-copper separators. Tungsten-carbide balls were used in a few tests. Experimental separators made of temperature-resistant, nonmetallic compositions were tried in a few tests.

The size 8502 (15-mm bore, 0.500-in. width) ball bearings in one of the $1 / 2-\mathrm{hp}, 3,450-\mathrm{rpm}$, driving motors were replaced with size $202 \mathrm{~K}^{\prime} \mathrm{TT}$ bearings (0.656-in. width) fitted with oil-soaked felt rings.

N.D. 5, S34-5-SS, and $34-5 \mathrm{~B}$ ball bearings $(5-\mathrm{mm}$ bore, $16-\mathrm{mm}$ o.d.) were used in tests with the airdriven gyro.

SS77034 and Q34 ball bearings (4-mm bore, $16-\mathrm{mm}$ o.d.) were used in tests with the high speed d-c motors. Tests with a magnet and with nitric acid indicated the separators in the SS77034 bearings were not stainless steel although the rings were stainless (presumably SAE No. 51440C). The Q34 bearings were made of conventional ball bearing steel, but fitted with phenolic-fabric nonmetallic separators. 


\subsection{Felts and Shields}

The polyester felt used for the data given in this paper has a nominal thickness of 0.130 in. and is described by the manufacturer as 3 denier, ST54, $1.25 \mathrm{lb} / \mathrm{yd}^{2}{ }^{2}$ When heated in an oven at $350^{\circ} \mathrm{F}$ for $500 \mathrm{hr}$ it remained pliable and tough; wool felt under the same conditions was charred and crumbly.

Teflon felt, having a nominal thickness of $0.125 \mathrm{in}$. and weighing $2.8 \mathrm{lb} / \mathrm{yd},{ }^{2}$ was used for tests at ambient temperatures above $350^{\circ} \mathrm{F}$. Layers of glass paper were used as felt in some tests.

The commercial extra wide $204 \mathrm{~K}$ ball bearings (such as Fafnir 204K'T') use felt rings between two metal shields to retain grease and exclude dirt. For the oil-soaked felt ring installations, new inner steel shields were made at NBS, with the depth increased from about 0.062 in. to about 0.102 in. This, with the 0.25 -in. depth of the commercial outer steel shield, provides about 0.127 -in. space for the oiled felt. Small holes $(1 / 16-i n$. diam) were drilled at the outer edge of the depression in the inner shields to facilitate creeping of the oil to the outer race of the bearing. For most of the tests a steel inner band was fitted to the inner shield to prevent stray felt fibers from touching the inner race of the bearing. In most of the tests a Teflon gasket $(0.015$-in. thick) was used between the felt and the outer steel shield. In figure 2, at the top, a bearing is shown before installation of the felt and shields and another with the outer shield staked in place; at the bottom, going from right to left is a bearing with an inner shield in place, a felt ring, a Teflon gasket, and the outer shield. There are only 4 holes in the inner shield shown, but shields with 16 holes were used for some of the tests.

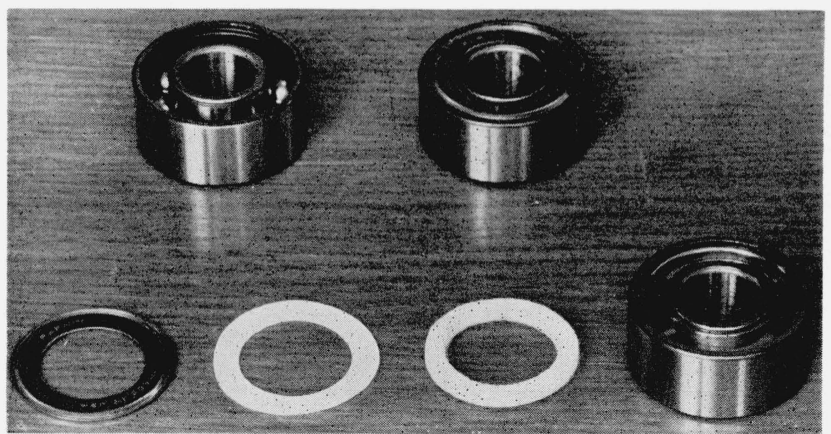

Figure 2. Method of felt installation in 204KTT (20- $\mathrm{mm}$ bore) ball bearings.

The steel inner shields for the $202 \mathrm{~K}$ TT ball bearings were proportionately smaller than the shields described above for $204 \mathrm{~K}^{\prime} \mathrm{T}$ T bearings, and were made in one piece instead of being fitted with separate inner bands.

\subsection{Lubricants}

The lubricants used in the tests covered by this paper are described in table 1 . Sample $\mathrm{SO}-15$ is the oil which was investigated for use in the temperature range from $-75^{\circ}$ to $+350^{\circ} \mathrm{F}$; most of the other oils were tried for a higher range of temperature. Tests with the greases were for comparative purposes.
TABLE 1. Lubricants

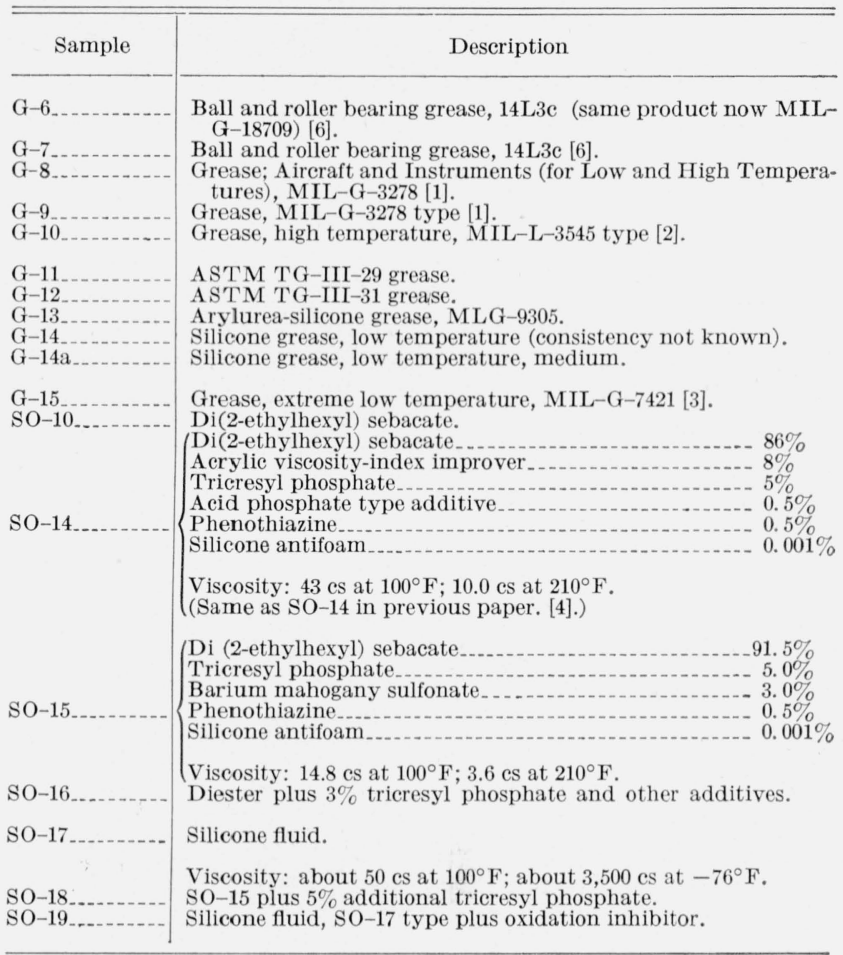

\section{Tests and Results}

\subsection{Endurance Machine Tests and Results}

a. Conventional Steel Bearings

Endurance tests with prelubricated $20-\mathrm{mm}$ bore ball bearings were run at $10,000 \mathrm{rpm}$, at ambient temperatures ranging from $80^{\circ}$ to $400^{\circ} \mathrm{F}$, with $3-\mathrm{lb}$ radial and 5-lb axial load. Dry cleaning solvent and benzene were used for cleaning the bearings before the prelubrication. The commercial bearing containing grease G-7 was used as received; with the other greases $3.0 \mathrm{~g}$ was used in each bearing. The motors and heaters were started at the same time, and sufficient heat was applied to raise the ambient to the selected test temperature within $1 \mathrm{hr}$; in general, the bearing temperature (outer race) was near or considerably beyond the ambient within the hour. After $22 \mathrm{hr}$ of operation each machine was stopped and allowed to cool for $2 \mathrm{hr}$ or more (occasionally stopped over weekends). Each test was continued with $22-\mathrm{hr}$ periods of operation until the bearing failed, as evidenced by excessive torque which operated the overload device or caused the belt to slip or throw off from the pulleys in cases of sudden seizure.

Most of these endurance tests were run for evaluating the performance of the ball bearings over a wide range of temperature when prelubricated with $\mathrm{SO}-15$ oil in polyester felts incorporated in the bearings. However, a few tests were run with a variety of greases for comparative purposes, and a few tests were run with other synthetic oils. 
Data for the endurance tests are given in table 2. The test with grease G-6 was for comparison with data obtained on previous machines [4] which did not provide the 5-lb axial load. In the previous tests, at $325^{\circ} \mathrm{F}$ bearing temperature, the endurance runs for this grease ranged from 178 to $330 \mathrm{hr}$; with the added $5-\mathrm{lb}$ axial load and $325^{\circ} \mathrm{F}$ ambient instead of bearing temperature, the endurance of $198 \mathrm{hr}$ is compatible with the data for the previous tests. It is believed that a lubricant which causes a bearing to operate at temperatures abnormally higher than the ambient temperature should not be favored by reducing the ambient to lower the bearing tempera-

TABLE 2.-Ball bearing endurance tests, at 10,000 rpm, with $3-l b$ radial and 5-lb axial loads, 20- $\mathrm{mm}$ bore, 52100-type steel

\begin{tabular}{|c|c|c|c|c|c|c|}
\hline \multirow{2}{*}{ Lubricant } & \multicolumn{2}{|c|}{ Bearing } & \multirow{2}{*}{$\begin{array}{l}\text { Type of } \\
\text { shield } \mathrm{c}\end{array}$} & \multirow{2}{*}{$\begin{array}{l}\text { Ambient } \\
\text { tempera- } \\
\text { ture }\end{array}$} & \multirow{2}{*}{$\begin{array}{c}\text { Hours run } \\
\text { before } \\
\text { failure }\end{array}$} & \multirow{2}{*}{$\begin{array}{l}\text { Separa- } \\
\text { tor broken }\end{array}$} \\
\hline & Size a & Stabilized b & & & & \\
\hline $\mathrm{G}-6 \ldots$ & $204 \mathrm{~K}$ & Yes_....... & 1 & ${ }^{\circ}{ }_{325}$ & 198 & No. \\
\hline G-7 & $204 \mathrm{KTT}$ & No... & 2 & 325 & 76 & No. \\
\hline $\begin{array}{l}\text { G-8 } \\
\text { G-9 } \\
\text { G-10 } \\
\text { G-13 } \\
\text { G-14a. } \\
\text { G-14a. } \\
\text { SO-10 }\end{array}$ & $\begin{array}{l}204 \mathrm{~K} \\
204 \mathrm{~K} \\
204 \mathrm{~K} \\
204 \mathrm{~K} \\
204 \mathrm{~K} \\
204 \mathrm{~K} \\
204 \mathrm{KTT}\end{array}$ & $\begin{array}{l}\text { Yes_. } \\
\text { Yes... } \\
\text { Yes... } \\
\text { Yes.. } \\
\text { Yes... } \\
\text { Yes... } \\
\text { Yes.... }\end{array}$ & $\begin{array}{l}1 \\
1 \\
1 \\
1 \\
1 \\
1 \\
3\end{array}$ & $\begin{array}{l}325 \\
325 \\
325 \\
325 \\
325 \\
325 \\
325\end{array}$ & $\begin{array}{c}32 \\
66 \\
85 \\
3,300+ \\
339 \\
1,011 \\
26\end{array}$ & $\begin{array}{l}\text { Yes. } \\
\text { No. } \\
\text { Yes. } \\
\text { No. } \\
\text { No. } \\
\text { Yes. } \\
\text { Yes. }\end{array}$ \\
\hline $\begin{array}{l}\text { SO-15 } \\
\text { SO-15.... }\end{array}$ & $\begin{array}{l}204 \mathrm{KTT} \\
204 \mathrm{KTT}\end{array}$ & $\begin{array}{l}\text { Yes....... } \\
\text { Yes....... }\end{array}$ & $\begin{array}{l}3 \\
3\end{array}$ & $\begin{array}{l}325 \\
325\end{array}$ & $\begin{array}{l}1,012 \\
1,618\end{array}$ & $\begin{array}{l}\text { Yes. } \\
\text { No. }\end{array}$ \\
\hline SO-15 $\ldots$ & $204 \mathrm{KTT}$ & Yes. & $3 \mathrm{a}$ & 325 & 750 & Yes. \\
\hline $\begin{array}{l}\text { SO-15. } \\
\text { SO-15. } \\
\text { SO- } 15\end{array}$ & $\begin{array}{l}204 \mathrm{KTT} \\
204 \mathrm{KTT} \\
204 \mathrm{KTT}\end{array}$ & $\begin{array}{l}\text { Yes_.... } \\
\text { Yes_... } \\
\text { Yes_... }\end{array}$ & $\begin{array}{l}3 \text { b } \\
3 \text { b } \\
3 \text { b }\end{array}$ & $\begin{array}{l}325 \\
325 \\
325\end{array}$ & $\begin{array}{r}248 \\
486 \\
1,119\end{array}$ & $\begin{array}{l}\text { Yes. } \\
\text { Yes. } \\
\text { Yes. }\end{array}$ \\
\hline $\begin{array}{l}\text { SO-15 } \\
\text { SO-15 }\end{array}$ & $\begin{array}{l}204 \mathrm{KTT} \\
204 \mathrm{KTT}\end{array}$ & $\begin{array}{l}\text { Yes... } \\
\text { Yes... }\end{array}$ & $\begin{array}{l}3 \text { 。 } \\
3 \text { 。 }\end{array}$ & $\begin{array}{l}325 \\
325\end{array}$ & $\begin{array}{l}484 \\
484\end{array}$ & $\begin{array}{l}\text { Yes. } \\
\text { Yes. }\end{array}$ \\
\hline $\begin{array}{l}\text { SO-15.- } \\
\text { SO-15.. }\end{array}$ & $\begin{array}{l}204 \mathrm{KTT} \\
204 \mathrm{KTT}\end{array}$ & $\begin{array}{l}\text { No } \\
\text { No... }\end{array}$ & $\begin{array}{l}4 \\
4\end{array}$ & $\begin{array}{l}80 \\
80\end{array}$ & $\begin{array}{l}1,590 \\
3,300+\end{array}$ & $\begin{array}{l}\text { Yes. } \\
\text { Yes. }\end{array}$ \\
\hline $\begin{array}{l}\text { SO-15 } \\
\text { SO-15 } \\
\text { SO-15... }\end{array}$ & $\begin{array}{l}204 \mathrm{KTT} \\
205 \mathrm{KTT}^{\prime} \mathrm{T} \\
204 \mathrm{KTT}^{\prime}\end{array}$ & $\begin{array}{l}\text { No } \\
\text { No_-.- } \\
\text { Ye3.- }\end{array}$ & $\begin{array}{l}4 \\
4 \\
4\end{array}$ & $\begin{array}{l}250 \\
250 \\
250\end{array}$ & $\begin{array}{c}708 \\
1,430 \\
3,300+\end{array}$ & $\begin{array}{l}\text { Yes. } \\
\text { Yes. } \\
\text { No. }\end{array}$ \\
\hline $\begin{array}{l}\text { SO-15 } \\
\text { SO-15. } \\
\text { SO-15- } \\
\text { SO-15 } \\
\text { SO-15 } \\
\text { SO-15 } \\
\text { SO-15. } \\
\text { SO-15. }\end{array}$ & $\begin{array}{l}204 \mathrm{KTT} \\
204 \mathrm{KTT} \\
204 \mathrm{KTT} \\
204 \mathrm{KTT} \\
204 \mathrm{KTT} \\
204 \mathrm{KTT} \\
204 \mathrm{KTT} \\
204 \mathrm{KTT}\end{array}$ & $\begin{array}{l}\text { No } \\
\text { No } \\
\text { No...... } \\
\text { No.... } \\
\text { No } \\
\text { Yes.... } \\
\text { Yes... } \\
\text { Yes... }\end{array}$ & $\begin{array}{l}4 \\
4 \\
4 \\
4 \\
4 \\
4 \\
4 \\
4\end{array}$ & $\begin{array}{l}300 \\
300 \\
300 \\
300 \\
300 \\
300 \\
300 \\
300\end{array}$ & $\begin{array}{r}440 \\
462 \\
508 \\
594 \\
924 \\
812 \\
930 \\
1,075\end{array}$ & $\begin{array}{l}\text { Yes. } \\
\text { Yes. } \\
\text { Yes. } \\
\text { No. } \\
\text { No. } \\
\text { Yes. } \\
\text { Yes. } \\
\text { No. }\end{array}$ \\
\hline $\begin{array}{l}\text { SO-15 } \\
\text { SO-15 } \\
\text { SO-15 }\end{array}$ & $\begin{array}{l}204 \mathrm{KTT} \\
204 \mathrm{KTT} \\
204 \mathrm{KTT}^{\prime}\end{array}$ & $\begin{array}{l}\text { Yes.- } \\
\text { Yes.- } \\
\text { Yes..- }\end{array}$ & $\begin{array}{l}4 \\
4 \\
4\end{array}$ & $\begin{array}{l}325 \\
325 \\
325\end{array}$ & $\begin{array}{l}424 \\
571 \\
708\end{array}$ & $\begin{array}{l}\text { Yes. } \\
\text { Yes. } \\
\text { No. }\end{array}$ \\
\hline SO-15_... & $204 \mathrm{KTT}$ & Yes_... & 4 & 350 & 195 & No. \\
\hline SO-14 & $204 \mathrm{KTT}$ & Yes... & 4 & 400 & 21 & Yes. \\
\hline SO-16 $\ldots$ & $204 \mathrm{KTT}$ & Yes.. & 4 & 325 & 99 & Yes. \\
\hline SO-16_. & $204 \mathrm{KTT}$ & Yes. & 4 & 400 & 25 & No. \\
\hline SO-18_..... & $204 \mathrm{KTT}$ & Yes_. & 4 & 300 & 281 & Yes. \\
\hline
\end{tabular}

a Nominal bearing width: $204 \mathrm{~K}=0.5512$ in.; $204 \mathrm{KTT}=0.8125 \mathrm{in}$.

b Stabilized bearings were heat stabilized during manufacture to minimize dimensional changes at high te nperature during use.

c Types of shields:

1. No shield in bearing; side plates of housing act as shields.

2. Commercial inner and outer steel shields with felt between. 3. NBS inner steel shields, 16 holes, polyester felts, commercial outer steel
shields not staked in place.

3a. Same as No. 3, with outer shields staked in place.

3b. Same as No. 3a, except with narrow Teflon gaskets.

3e Same as No. 3b, except with inner band.

4. NBS inner steel shields, 4 holes, inner band, polyester felt (Teflon felt at $400^{\circ} \mathrm{F}$ ), wide Teflon gaskets, commercial outer steel shields staked in place. ture. Accordingly, the ambient temperature was used as the controlled temperature in this later work.

The test with grease $\mathrm{G}-\mathbf{7}$ was with a commercially obtained extra wide $204 \mathrm{~K}$ bearing as prelubricated at the factory with a 14L3c [6] grease believed to be similar to grease $\mathrm{G}-5$ in the previous paper [4].

Grease $\mathrm{G}-8$ is a well-known MIL-G-3278 [1] grease obtained commercially. Grease G-9 is a sample tested by another laboratory for high-temperature performance in accordance with MIL-G-3278; at $250^{\circ} \mathrm{F}$ bearing temperature and $10,000 \mathrm{rpm}$ the endurance life was $1,385,1,361,1,281$, and $1,767 \mathrm{hr}$, with an average of $1,449 \mathrm{hr}(1,000 \mathrm{hr}$ required).

Grease $\mathrm{G}-10$ is a sample tested by another laboratory for high-temperature performance in accordance with MIL-L-3545; at $300^{\circ} \mathrm{F}$ bearing temperature and $10,000 \mathrm{rpm}$ the endurance life was $1,477,2,146$, 1,231 , and 1,521, with an average of $1,594 \mathrm{hr}(600 \mathrm{hr}$ required).

Although greases G-7 and G-8 are satisfactory at $212^{\circ}$ and $250^{\circ} \mathrm{F}$ respectively, and greases $\mathrm{G}-9$ and $\mathrm{G}-10$ exceed the specification requirements at $250^{\circ}$ and $300^{\circ} \mathrm{F}$ respectively, the endurance life with each at $325^{\circ} \mathrm{F}$ ambient temperature and $10,000 \mathrm{rpm}$ is very short (less than $100 \mathrm{hr}$ ).

Grease G-13 (MLG-9305) was tested at Wright Air Development Center in accordance with CRC Method L-35 (specified in MIL-G-25013 [7]) on the Navy-type spindle; with high-speed tool steel bearings, at $450^{\circ} \mathrm{F}$ and $10,000 \mathrm{rpm}$, the endurance life was 368 and $596 \mathrm{hr}$, with an average of $482 \mathrm{hr}$. A test with this grease in a heat stabilized 52100-type bearing was ended at $3,300 \mathrm{hr}$ without failure, at $325^{\circ} \mathrm{F}$. However, this grease gives excessive torque at low temperatures (see section 4.2).

Grease 14a is recommended (on the container) for operating temperatures from $-100^{\circ}$ to $+300^{\circ} \mathrm{F}$. The average of $675 \mathrm{hr}$ for 2 tests at $325^{\circ} \mathrm{F}$ ambient temperature and the low torque at $-75^{\circ} \mathrm{F}$ (see section 4.2) are in agreement with the recommendation. Tests with grease 14 were conducted at another laboratory several years ago at $250^{\circ}$ and $300^{\circ} \mathrm{F}$, with results averaging 2,473 and $1,741 \mathrm{hr}$, respectively. However, this grease is not qualified under any military specification.

The test with oil SO-10 was for comparison with data obtained on a previous machine [4] which did not provide the 5-lb axial load. In the previous test at $325^{\circ} \mathrm{F}$ bearing temperature, the endurance of $48 \mathrm{hr}$ is compatible with the endurance of $26 \mathrm{hr}$ in the test at $325^{\circ} \mathrm{F}$ ambient temperature with a 5 -lb axial load.

In two tests with SO-15 oil, NBS inner shields were used and commercial outer shields were held in place with spacers between the shields ard the housing side plates. Both of these tests exceeded $1,000 \mathrm{hr}$ in duration at $325^{\circ} \mathrm{F}$. However, this type of shield installation (type 3 in table 2 ) was considered undesirable because it would require installation of felts and fitting with spacers in service installation of bearings. Accordingly, a test was made with the outer shields staked in place in the same manner (type 3a) used for commercial 204KTT ball 
bearings, and in this test failure occurred at $750 \mathrm{hr}$ at $325^{\circ} \mathrm{F}$. In these three tests there was an undesirable amount of oil seepage from the bearings during the first hour of operation. Accordingly, other methods (see 3b, 3c, and 4 at end of table 2) of shield installation were tried.

In most of the endurance tests, NBS inner shields with 4 holes each (see fig. 2) were used with an inner band to prevent stray felt fibers from touching the inner race, and a Teflon gasket was used between each felt and outer shield to prevent oil seepage from the bearing. The data for the tests with $\mathrm{SO}-15$ oil and polyester felt, at $10,000 \mathrm{rpm}$, are shown in figure 3 , with solid points for the type 4 shields, and open circles for the other types of shielding. The straight line in this figure is based on $1,000 \mathrm{hr}$ at $250^{\circ} \mathrm{F}$ and $600 \mathrm{hr}$ at $300^{\circ} \mathrm{F}$, which are the requirements in MIL-G-3278 [1] and MIL-L-3545 [2] respectively, except that these grease specifications use bearing temperatures instead of ambient temperatures. This line may be represented by the equation $L=3,000-8 T$, where $L$ represents the endurance life in hours and $T$ represents the temperature in degrees Fahrenheit. The averages of endurance data for these tests at $80^{\circ}, 250^{\circ}, 300^{\circ}$, and $325^{\circ} \mathrm{F}$ ambient temperatures are above the line in each case.

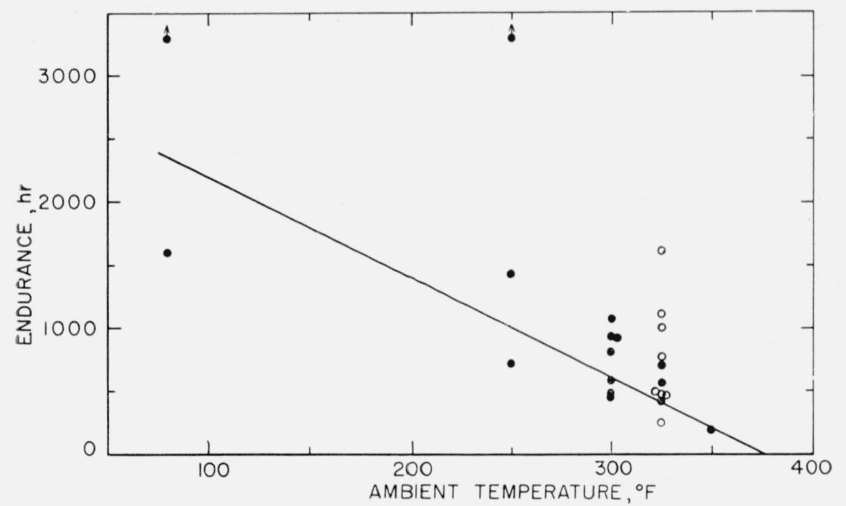

Figure 3. Effect of temperature on endurance tests with 20$\mathrm{mm}$ bore ball bearings, at $10,000 \mathrm{rpm}$, prelubricated with SO15 oil in polyester felt pads.

The straight line is based on $1,000 \mathrm{hr}$ at $250^{\circ} \mathrm{F}$ and $600 \mathrm{hr}$ at $300^{\circ} \mathrm{F}$, the requirements in MIL-G-3278 and MIL-L-3545, respectively.

Exploratory tests with lubricants SO-14 and SO-16 indicated they were not suitable for prelubrication at $400^{\circ} \mathrm{F}$. Also, a test with lubricant $\mathrm{SO}-18$ at $300^{\circ} \mathrm{F}$ did not indicate any advantage in adding more tricresyl phosphate to lubricant SO-15.

As shown in table 2, broken separators caused the failures in most of the tests with oil-prelubricated bearings, apparently by jamming the balls in the races. However, in one test at $80^{\circ} \mathrm{F}$ the bearing was in operating condition at the end of $3,300 \mathrm{hr}$ although a small segment was broken from the separator. At the end of the tests at high temperature with $\mathrm{SO}-15$ oil varnishlike films were observed on the races and balls. These films were not continuous but were broken and uneven in thickness. In some cases (especially at $300^{\circ} \mathrm{F}$ ) failures resulted from these films causing binding (no clearance).
On the other hand, it is probable that the formation of the film is the mechanism whereby the $\mathrm{SO}-15$ oil provides satisfactory operation at temperatures up to $325^{\circ} \mathrm{F}$ for many hours after the supply of oil is exhausted.

\section{b. High-Speed Tool Steel Bearings at 10,000 rpm}

Endurance tests were made with high-speed tool steel ball bearings (20-mm bore) at 10,000 rpm and $450^{\circ} \mathrm{F}$ ambient temperature. The data for these tests are given in table 3 . In these tests the machined and riveted $\mathrm{M}-2$ steel separators did not leave sufficient space in the size $204 \mathrm{~K}$ T'T $(0.8125 \mathrm{in}$. width) bearings for installing the special NBS inner steel shields; accordingly, the commercial inner shields were used after drilling 16 holes in each shield (similar to type 3 in table 2 except for depth). With the size $204 \mathrm{~K}$ (0.5512 in. width) bearings, the felts were installed in rings on each side of the bearings as described in the previous paper [4].

In two tests with unhardened $\mathrm{M}-2$ steel separators the separators broke in 16 and $15 \mathrm{hr}$. In addition to the breaks, several cracks were present in the separators at the ball pockets. It is believed that, after the lubricant was exhausted, vibration from "stick-slip" of the land-riding separators stressed the unhardened steel beyond its elastic limit and quickly induced fatigue cracks.

In the tests with hardened M-2 steel separators no breaks or fractures were observed. However, in general, the bearings became noisy and the friction became excessively high after exhaustion of the lubricant; but in some cases the bearings and separators were found to be in good condition after being cleaned and examined at the end of the tests.

Tests with the SO-15 oil indicated that at $450^{\circ} \mathrm{F}$ ambient temperature it did not form a varnishlike film which would provide satisfactory operation after the oil was exhausted; and its volatility at $450^{\circ} \mathrm{F}$ caused exhaustion of the oil in the bearings in a relatively short time.

Tests with the less volatile oils $\mathrm{SO}-16, \mathrm{SO}-17$, and SO-19 indicated they were not suitable for prelubrication at $450^{\circ} \mathrm{F}$ ambient temperature although they lasted somewhat longer than the SO-15 oil.

The silver-plated beryllium-copper separators (currently being used for grease prelubricated bearings at $450^{\circ} \mathrm{F}$ ) appeared to be the most suitable of the separators tried in these tests, with $52 \mathrm{hr}$ of operation with SO-15 oil and $155 \mathrm{hr}$ of operation with SO19 oil. It is believed that a large part of this operation occurred after the supply of oil was exhausted in each case.

A separator made of asbestos-fiber reinforced high-temperature phenolic composition failed at $116 \mathrm{hr}$ of operation because of excessive wear and breakage after the supply of SO-19 oil was exhausted by evaporation. A separator made of oriented glassfiber reinforced composition rovings failed in $9 \mathrm{hr}$ because of breaking into halves in the plane of the ball centers.

Endurance (16 hr) with an M-2 steel ball bearing 
TABLE 3. Ball bearing endurance tests, at 10,000 r pm, at 450 $\mathrm{F}$ ambient temperature, with 3-lb radial and 5-lb axial loads, 20-mm bore, high-speed tool steel

\begin{tabular}{|c|c|c|c|c|c|c|c|c|}
\hline \multirow{2}{*}{ Lubricant } & \multicolumn{2}{|c|}{ Bearing } & \multicolumn{2}{|c|}{ Separator } & \multirow{2}{*}{ Sulfurized } & \multirow{2}{*}{ Felt } & \multirow{2}{*}{$\begin{array}{l}\text { Hours } \\
\text { run } \\
\text { before } \\
\text { failure }\end{array}$} & \multirow{2}{*}{$\begin{array}{l}\text { Separator } \\
\text { broken }\end{array}$} \\
\hline & Size & Steel & Material & Hardened & & & & \\
\hline $\begin{array}{l}\mathrm{SO}-15 \ldots \\
\mathrm{SO}-15_{\ldots} \\
\mathrm{SO}-15_{\ldots} \ldots \ldots\end{array}$ & $\begin{array}{ll}204 & \mathrm{~K} T \mathrm{~T} \\
204 & \mathrm{~K} \\
204 & \mathrm{~K} \mathrm{TT}\end{array}$ & $\begin{array}{l}\text { M-2 } \\
\text { M-10 } \\
\text { M-2 }\end{array}$ & $\begin{array}{l}\mathrm{M}-2 \\
(1) \\
(2)\end{array}$ & Yes.. & $\begin{array}{l}\text { Yes.- } \\
\text { No }{ }_{---} \\
\mathrm{No}_{--}\end{array}$ & $\begin{array}{l}\text { Teflon } \ldots \ldots \\
\text { Teflon } \\
\text { Teflon } \ldots \ldots\end{array}$ & $\begin{array}{r}9 \\
52 \\
6\end{array}$ & $\begin{array}{l}\text { No. } \\
\text { Yes. }\end{array}$ \\
\hline $\begin{array}{l}\mathrm{SO}-16 \ldots \\
\mathrm{SO}-16_{\ldots}\end{array}$ & $\begin{array}{l}204 \text { KTT } \\
204 \text { KTT }\end{array}$ & $\begin{array}{l}\text { M-2 } \\
\text { M-2 }\end{array}$ & $\begin{array}{l}\mathrm{M}-2 \\
\mathrm{M}-2\end{array}$ & $\begin{array}{l}\text { No } \\
\text { Yes... }\end{array}$ & $\begin{array}{l}\mathrm{No}_{---} \\
\mathrm{No} \mathrm{L}_{--}\end{array}$ & $\begin{array}{l}\text { Teflon } \\
\text { Teflon }\end{array}$ & $\begin{array}{l}16 \\
13\end{array}$ & $\begin{array}{l}\text { Yes. } \\
\text { No. }\end{array}$ \\
\hline $\begin{array}{l}\mathrm{SO}-17 \ldots \\
\mathrm{SO}-17 \ldots\end{array}$ & $\begin{array}{l}204 \text { KTT } \\
204 \text { KTT }\end{array}$ & $\begin{array}{l}\text { M-2 } \\
\text { M-2 }\end{array}$ & $\begin{array}{l}\mathrm{M}-2 \\
\mathrm{M}-2\end{array}$ & $\begin{array}{l}\text { No_-- } \\
\text { Yes.- }\end{array}$ & $\begin{array}{l}\text { No } \\
\text { Yes-- }\end{array}$ & $\begin{array}{l}\text { Teflon } \ldots \\
\text { Teflon }\end{array}$ & $\begin{array}{l}15 \\
33\end{array}$ & $\begin{array}{l}\text { Yes. } \\
\text { No. }\end{array}$ \\
\hline $\begin{array}{l}\text { SO }-19 \\
\text { SO } 19 \\
\text { SO } 19 \\
\text { SO } 19 \\
\text { SO } 19 \\
\text { SO } 19 \\
\text { SO } 19 \\
\text { SO } 19\end{array}$ & $\begin{array}{ll}204 & \mathrm{KTT} \\
204 & \mathrm{KTT} \\
204 & \mathrm{~K} \\
204 & \mathrm{~K} \\
204 & \mathrm{KTT} \\
204 & \mathrm{~K} \\
204 & \mathrm{KTT} \\
204 & \mathrm{~K}\end{array}$ & $\begin{array}{l}\text { M-2 } \\
\text { M-2 } \\
\text { M-2 } \\
\text { M-10 } \\
(3) \\
\text { M-2 } \\
\text { M-2 } \\
\text { M-2 }\end{array}$ & $\begin{array}{l}\mathrm{M}-2 \\
\mathrm{M}-2 \\
\mathrm{M}-2 \\
(1) \\
(3) \\
(4) \\
(5) \\
(6)\end{array}$ & $\begin{array}{l}\text { Yes... } \\
\text { Yes_... } \\
\text { Yes... }\end{array}$ & 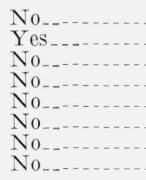 & $\begin{array}{l}\text { Glass } \\
\text { Glass } \\
\text { Teflon } \\
\text { Teflon } \\
\text { Teflon } \\
\text { Teflon } \\
\text { Teflon } \\
\text { Teflon }\end{array}$ & $\begin{array}{r}8 \\
12 \\
42 \\
155 \\
44 \\
30 \\
9 \\
116\end{array}$ & $\begin{array}{l}\text { No. } \\
\text { No. } \\
\text { No. } \\
\text { Yes. } \\
\text { No. } \\
\text { Yes. } \\
\text { Yes. }\end{array}$ \\
\hline $\mathrm{MoS}_{2} \ldots$ & $204 \mathrm{KTT}$ & $\mathrm{M}-2$ & $\mathrm{M}-2$ & Yes...... & Yes $\ldots . . . .$. & None & 16 & No. \\
\hline $\begin{array}{l}\text { None........... } \\
\text { None......... }\end{array}$ & $\begin{array}{l}204 \text { KTT } \\
204 \text { KTT }\end{array}$ & $\begin{array}{l}\mathrm{M}-2 \\
\mathrm{M}-2\end{array}$ & $\begin{array}{l}\mathrm{M}-2 \\
\mathrm{M}-2\end{array}$ & $\begin{array}{l}\text { Yes...- } \\
\text { Yes } \ldots . .\end{array}$ & $\begin{array}{l}\text { Yes } \\
\text { No }\end{array}$ & 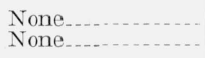 & $\begin{array}{l}88 \\
12\end{array}$ & $\begin{array}{l}\text { No. } \\
\text { No. }\end{array}$ \\
\hline
\end{tabular}

1 Silver-plated beryllium-copper separator

2 Balls as separators, $9 / 32$-in. diam, type 52100.

3 M-2 steel rings with tungsten-carbide balls; 7 balls $5 / 16$-in. diam for load, 7 balls $9 / 32$-in. diam for spacing.

Silver-plated hardened M-2 steel separator.

5 Glass-fiber reinforced high-temperature molded composition.

${ }^{6}$ Asbestos-fiber reinforced high-temperature phenolic composition.

prelubricated with molybdenum disulfide powder was not significantly better than with an unlubricated bearing which failed in $12 \mathrm{hr}$. A sulfurized unlubricated bearing continued in operation $88 \mathrm{hr}$ when failure occurred with broken rivets in the separator; the balls, races, and separator were worn excessively and, even before final failure, the bearing would not have been satisfactory in applications where large radial play of the shaft could not be tolerated.

\section{c. High-Speed Tool Steel Bearings at 5,000 rpm}

Three endurance tests were made with high-speed tool steel ball bearings $(20-\mathrm{mm}$ bore) at 5,000 rpm and $650^{\circ} \mathrm{F}$ ambient temperature.

One test was made with M-2 steel rings fitted with tungsten carbide balls; 7 balls $5 / 16$ in. in diam for supporting the load and 7 balls $9 / 32$ in. in diam for spacing the load balls. A coating of SO-15 oil was applied to the bearing and it was operated $22 \mathrm{hr}$ at room temperature for "run-in" before testing at $650^{\circ} \mathrm{F}$. No oil-soaked felt was used, and it is probable that all the oil in the bearing evaporated during the first hour while being heated to $650^{\circ} \mathrm{F}$. The thermocouple nearly touching the outer ring reached $750^{\circ} \mathrm{F}$ with the $650^{\circ} \mathrm{F}$ ambient temperature, and it is probable that the ball and race temperatures were much higher than $750^{\circ} \mathrm{F}$. One of the lands of the inner ring had been ground to a smaller diameter to make this a separable bearing to permit installing the balls to fill the raceway; failure occurred after $88 \mathrm{hr}$ of operation at $650^{\circ} \mathrm{F}$ ambient temperature when two of the spacer balls escaped the raceway. The races were worn considerably and "spalling" was observed on the balls when examined with a 10-power stereomicroscope.
Two tests were made with sulfurized M-2 steel bearings and separators (hardened) at $650^{\circ} \mathrm{F}$ ambient temperature and 5,000 rpm, without lubrication. One of these bearings, sulfurized after assembly, failed after $10 \mathrm{hr}$ of operation, because of high torque. It was worn exeessively. The other bearing, sulfurized before assembly, was inspected after $550 \mathrm{hr}$ of operation. The balls, races, and separator were worn excessively, and the separator rivets were broken. Apparently, the inner race had been sliding on some of the balls, with the bearing no longer functioning as a ball bearing. Although the bearing was operating in the endurance machine without excessive torque at the end of $550 \mathrm{hr}$, the condition of the bearing was such that it would not have been satisfactory in applications where large radial play of the shaft could not be tolerated.

\subsection{Friction Machine Tests and Results}

Frictional torque and bearing temperature rise above the ambient were investigated with two greases and with $\mathrm{SO}-15$ oil in felt rings, at speeds ranging from 10 to $8,500 \mathrm{rpm}$. The data for these tests with grease $\mathrm{G}-8$ are given in table 4 . A clean $204 \mathrm{~K}$ bearing was lubricated with $3.0 \mathrm{~g}$ of grease in the conventional manner, with rotation by hand to ensure the presence of grease in the races. Starting at $10 \mathrm{rpm}$, the torque in gram-centimeters and the temperature rise above the ambient were determined near the end of the first and the tenth minute, at room temperature $\left(80^{\circ} \mathrm{F}\right.$ nominal $)$. Then the speed was increased in steps to $100,500,1,000,2,000,4,900$, and $8,500 \mathrm{rpm}$, with $10 \mathrm{~min}$ of operation at each speed, and readings were taken for the first and tenth minute at each speed. With the same bearing, with- 
TABLE 4. Frictional torque and bearing temperature rise above ambient for a $20-\mathrm{mm}$ bore ball bearing lubricaled with $3.0 \mathrm{~g}$ of $G-8$ grease, with $4-l b$ nominal radial load

\begin{tabular}{|c|c|c|c|c|c|c|c|c|c|}
\hline \multirow{3}{*}{ Speed } & \multirow{3}{*}{$\begin{array}{l}\text { Time } \\
\text { at } \\
\text { each } \\
\text { speed }\end{array}$} & \multicolumn{8}{|c|}{ Nominal ambient temperature, ${ }^{\circ} \mathrm{F}$} \\
\hline & & \multicolumn{2}{|c|}{80} & \multicolumn{2}{|c|}{-40} & \multicolumn{2}{|c|}{-75 , blower on } & \multicolumn{2}{|c|}{80} \\
\hline & & Torque & $\Delta \mathrm{T}$ & Torque & $\Delta \mathrm{T}$ & Torque & $\Delta \mathrm{T}$ & Torque & $\Delta \mathrm{T}$ \\
\hline $\begin{array}{r}r p m \\
10 \\
10\end{array}$ & $\begin{array}{r}\min \\
1 \\
10\end{array}$ & $\begin{array}{r}g-c m \\
99 \\
45\end{array}$ & $\begin{array}{r}\circ{ }^{\circ} \\
0 \\
0\end{array}$ & $\begin{array}{r}g-c m \\
25 \\
25\end{array}$ & $\begin{array}{r}{ }^{\circ} F \\
10 \\
10\end{array}$ & $\begin{array}{r}g-c m \\
403 \\
252\end{array}$ & $\begin{array}{r}\circ F \\
1 \\
1\end{array}$ & $\begin{array}{r}\text { g-cm } \\
45 \\
41\end{array}$ & ${ }^{\circ}{ }^{F}{ }_{0}$ \\
\hline $\begin{array}{l}100 \\
100\end{array}$ & $\begin{array}{r}1 \\
10\end{array}$ & $\begin{array}{l}72 \\
29\end{array}$ & $\begin{array}{l}0 \\
0\end{array}$ & $\begin{array}{l}113 \\
113\end{array}$ & $\begin{array}{l}10 \\
10\end{array}$ & $\begin{array}{r}113 \\
88\end{array}$ & $\begin{array}{l}1 \\
1\end{array}$ & $\begin{array}{l}34 \\
26\end{array}$ & $\begin{array}{l}0 \\
0\end{array}$ \\
\hline $\begin{array}{l}500 \\
500\end{array}$ & $\begin{array}{r}1 \\
10\end{array}$ & $\begin{array}{l}48 \\
32\end{array}$ & $\begin{array}{l}0 \\
0\end{array}$ & $\begin{array}{l}277 \\
202\end{array}$ & $\begin{array}{l}11 \\
12\end{array}$ & $\begin{array}{l}113 \\
101\end{array}$ & $\begin{array}{l}1 \\
1\end{array}$ & $\begin{array}{l}48 \\
40\end{array}$ & $\begin{array}{l}0 \\
0\end{array}$ \\
\hline $\begin{array}{l}1,000 \\
1,000\end{array}$ & $\begin{array}{r}1 \\
10\end{array}$ & $\begin{array}{l}64 \\
48\end{array}$ & $\begin{array}{l}0 \\
0\end{array}$ & $\begin{array}{l}277 \\
101\end{array}$ & $\begin{array}{l}12 \\
13\end{array}$ & $\begin{array}{l}88 \\
50\end{array}$ & $\begin{array}{l}1 \\
1\end{array}$ & $\begin{array}{l}68 \\
68\end{array}$ & $\begin{array}{l}0 \\
0\end{array}$ \\
\hline $\begin{array}{l}2,000 \\
2,000\end{array}$ & $\begin{array}{r}1 \\
10\end{array}$ & $\begin{array}{l}90 \\
90\end{array}$ & $\begin{array}{l}0 \\
1\end{array}$ & $\begin{array}{l}151 \\
202\end{array}$ & $\begin{array}{l}13 \\
13\end{array}$ & $\begin{array}{l}50 \\
38\end{array}$ & $\begin{array}{l}1 \\
1\end{array}$ & $\begin{array}{r}113 \\
99\end{array}$ & $\begin{array}{l}0 \\
1\end{array}$ \\
\hline $\begin{array}{l}4,900 \\
4,900\end{array}$ & $\begin{array}{r}1 \\
10\end{array}$ & $\begin{array}{l}378 \\
328\end{array}$ & $\begin{array}{r}4 \\
13\end{array}$ & $\begin{array}{l}328 \\
328\end{array}$ & $\begin{array}{l}14 \\
29\end{array}$ & $\begin{array}{l}277 \\
126\end{array}$ & $\begin{array}{l}2 \\
3\end{array}$ & $\begin{array}{l}378 \\
328\end{array}$ & $\begin{array}{r}4 \\
12\end{array}$ \\
\hline $\begin{array}{l}8,500 \\
8,500\end{array}$ & $\begin{array}{r}1 \\
10\end{array}$ & $\begin{array}{l}504 \\
227\end{array}$ & $\begin{array}{l}17 \\
27\end{array}$ & $\begin{array}{l}882 \\
757\end{array}$ & $\begin{array}{l}38 \\
80\end{array}$ & $\begin{array}{l}2,520 \\
1,310\end{array}$ & $\begin{array}{r}27 \\
102\end{array}$ & $\begin{array}{l}504 \\
227\end{array}$ & $\begin{array}{l}18 \\
27\end{array}$ \\
\hline
\end{tabular}

out repacking, similar tests were made at an ambient temperature of $-40^{\circ} \mathrm{F}\left(-40^{\circ} \mathrm{C}\right)$ with no forced air circulation, at $-75^{\circ} \mathrm{F}\left(-59.4^{\circ} \mathrm{C}\right)$ with forced air circulation (except when reading torque), and at $80^{\circ} \mathrm{F}\left(26.7^{\circ} \mathrm{C}\right)$, respectively. In each case, the bearing stood overnight between tests at the different ambient temperatures.

Similarly, data obtained with grease G-9 are given in table 5. With each of the two greases, at $-75^{\circ} \mathrm{F}$ ambient temperature, the bearing temperature rise exceeded $100^{\circ} \mathrm{F}$ after $10 \mathrm{~min}$ of operation at 8,500 rpm with forced air circulation, and the torque exceeded 1,000 g-cm.

Torque and temperature-rise data were obtained in a similar manner with extra wide $204 \mathrm{~K}$ ball bearings prelubricated with polyester felt rings soaked in SO-15 oil. Data are given in table 6 , for a bearing fitted with inner shields having 4 holes each and

TABLE 5. Frictional torque and bearing temperature rise above ambient for a $20-m m$ bore ball bearing lubricated with $3.0 \mathrm{~g}$ of $G-9$ grease, with 4-lb nominal radial load

\begin{tabular}{|c|c|c|c|c|c|c|c|c|c|}
\hline \multirow{3}{*}{ Speed } & \multirow{3}{*}{$\begin{array}{c}\text { Time } \\
\text { at } \\
\text { each } \\
\text { speed }\end{array}$} & \multicolumn{8}{|c|}{ Nominal ambient temperature, ${ }^{\circ} \mathrm{F}$} \\
\hline & & \multicolumn{2}{|c|}{80} & \multicolumn{2}{|c|}{-40} & \multicolumn{2}{|c|}{-75 , blower on } & \multicolumn{2}{|c|}{80} \\
\hline & & Torque & $\Delta \mathrm{T}$ & Torque & $\Delta \mathrm{T}$ & Torque & $\Delta \mathrm{T}$ & Torque & $\Delta \mathrm{T}$ \\
\hline $\begin{array}{r}r p m \\
10 \\
10\end{array}$ & $\begin{array}{r}\min \\
1 \\
10\end{array}$ & $\begin{array}{r}g-c m \\
203 \\
203\end{array}$ & $\begin{array}{r}\circ F \\
0 \\
0\end{array}$ & $\begin{array}{r}g-c m \\
302 \\
302\end{array}$ & $\begin{array}{c}\circ F \\
10 \\
10\end{array}$ & $\begin{array}{l}g-c m \\
1.560 \\
1,760\end{array}$ & $\begin{array}{r}\circ{ }^{\circ} \\
2 \\
2\end{array}$ & $\begin{array}{r}\text { g-cm } \\
158 \\
181\end{array}$ & $\begin{array}{r}{ }^{\circ} F \\
\quad 0 \\
0\end{array}$ \\
\hline 100 & 1 & 203 & 0 & 630 & 11 & 1,060 & 2 & 136 & 0 \\
\hline 100 & 10 & 172 & 0 & 630 & 11 & 882 & 2 & 118 & 0 \\
\hline 500 & 1 & 217 & 0 & 1,460 & 12 & 1,260 & 2 & 140 & 0 \\
\hline 500 & 10 & 21 & 1 & 1,080 & 18 & 958 & 3 & 145 & 1 \\
\hline 1,000 & 1 & 27 & 1 & 1,260 & 20 & 95 & 4 & 194 & 1 \\
\hline 1,000 & 10 & 253 & 3 & 504 & 23 & 832 & 10 & 185 & 2 \\
\hline 2,000 & 1 & 31 & 3 & 479 & 24 & 882 & 12 & 217 & 3 \\
\hline 2,000 & 10 & 217 & 5 & 353 & 27 & 857 & 19 & 190 & 4 \\
\hline 4,900 & 1 & 50 & 9 & 1,510 & 35 & 2,520 & 43 & 302 & 6 \\
\hline 4,900 & 10 & 353 & 20 & 932 & 70 & 1,640 & 84 & 227 & 14 \\
\hline 8,500 & 1 & 60 & 24 & 1,080 & 78 & 1,510 & 94 & 454 & 20 \\
\hline 8,500 & 10 & 466 & 48 & 756 & 100 & 1,010 & 109 & 353 & 36 \\
\hline
\end{tabular}

TABLE 6.-Frictional torque and bearing temperature rise above ambient for a 20-mm bore ball bearing lubricated with polyester felt rings soaked in SO-15 oil, with 4-pound nominal radial load

\begin{tabular}{|c|c|c|c|c|c|c|c|c|c|}
\hline \multirow{3}{*}{ Speed } & \multirow{3}{*}{$\begin{array}{l}\text { Time } \\
\text { at } \\
\text { each } \\
\text { speed }\end{array}$} & \multicolumn{8}{|c|}{ Nominal ambient temperature, ${ }^{\circ} \mathrm{F}$} \\
\hline & & \multicolumn{2}{|l|}{80} & \multicolumn{2}{|c|}{-40} & \multicolumn{2}{|c|}{-75 , blower on } & \multicolumn{2}{|c|}{80} \\
\hline & & Torque & $\Delta \mathrm{T}$ & Torque & $\Delta \mathrm{T}$ & Torque & $\Delta \mathrm{T}$ & Torque & $\Delta \mathrm{T}$ \\
\hline $\begin{array}{r}r p m \\
10 \\
10\end{array}$ & $\begin{array}{r}\min \\
1 \\
10\end{array}$ & $\begin{array}{r}g-\mathrm{cm} \\
8 \\
8\end{array}$ & $\begin{array}{r}\circ F \\
0 \\
0\end{array}$ & $\begin{array}{r}g-c m \\
4 \\
4\end{array}$ & $\begin{array}{c}{ }^{\circ} F \\
10 \\
10\end{array}$ & $\begin{array}{r}g-c m \\
54 \\
54\end{array}$ & $\begin{array}{r}\circ F \\
1 \\
1\end{array}$ & $\begin{array}{r}g-\mathrm{cm} \\
8 \\
8\end{array}$ & ${ }^{\circ} F_{0}$ \\
\hline 100 & 1 & 10 & 0 & 14 & 10 & 108 & 1 & 6 & 0 \\
\hline 100 & 10 & 8 & 0 & 14 & 10 & 113 & 1 & 6 & 0 \\
\hline 500 & 1 & 18 & 0 & 50 & 10 & 63 & 1 & 10 & $\begin{array}{l}0 \\
0\end{array}$ \\
\hline & 10 & & 0 & 50 & 1 & 50 & 1 & 10 & \\
\hline 1,000 & 1 & 32 & 0 & 108 & 11 & 41 & 1 & 13 & 0 \\
\hline 1,000 & 10 & 32 & 1 & 100 & 12 & 36 & .1 & 13 & 0 \\
\hline 2,000 & 1 & 67 & 1 & 136 & 1. & 27 & 1 & 26 & 0 \\
\hline 2,000 & 10 & 67 & 1 & 127 & 12 & 23 & 1 & 26 & 0 \\
\hline 4,900 & 1 & 145 & 1 & 362 & 14 & 12 & 1 & 51 & 0 \\
\hline 4,900 & 10 & 131 & 6 & 325 & 23 & 118 & 2 & 51 & 2 \\
\hline 8,500 & 1 & 99 & 6 & 158 & 24 & 46 & 3 & 80 & 3 \\
\hline 8,500 & 10 & 77 & 7 & 127 & 24 & 36 & 3 & 64 & 4 \\
\hline
\end{tabular}

Note: $O$ il in bearing and felt; at start $=2.93 \mathrm{~g}$; at end of testing $=2.13 \mathrm{~g}$.

inner bands, but without the Teflon gaskets. The torque and the temperature rise at $-75^{\circ} \mathrm{F}$ and $8,500 \mathrm{rpm}$ are very low in comparison with the data for the greased bearings. However, there was an undesirable loss of oil from the bearing (see table 6) during the friction testing. Accordingly, a similar test was made with Teflon gaskets $(0.015$-in. thick) used between the felts and the outer shields, and these data are given in table 7 . The gaskets reduced the loss of oil, and it is assumed that the greater amount of oil remaining in the races caused the torque at $-75^{\circ} \mathrm{F}$ ambient temperature to be higher than in the previous test in which more oil was lost.

The loss of oil from the bearings is undesirable.

TABLE 7.-Frictional torque and bear ing temperature rise above ambient for a 20- $\mathrm{mm}$ bore ball bearing lubricated with polyester felt rings soaked in $\mathrm{SO}-15$ oil, with teflon gaskets, with 4-lb nominal radial load

\begin{tabular}{|c|c|c|c|c|c|c|c|c|c|}
\hline \multirow{3}{*}{ Speed } & \multirow{3}{*}{$\begin{array}{l}\text { Time } \\
\text { at } \\
\text { each } \\
\text { speed }\end{array}$} & \multicolumn{8}{|c|}{ Nominal ambient temperature, ${ }^{\circ} \mathrm{F}$} \\
\hline & & \multicolumn{2}{|l|}{80} & \multicolumn{2}{|c|}{-40} & \multicolumn{2}{|c|}{-75 , blower on } & \multicolumn{2}{|c|}{80} \\
\hline & & Torque & $\Delta \mathrm{T}$ & Torque & $\Delta \mathrm{T}$ & Torque & $\Delta \mathrm{T}$ & Torque & $\Delta \mathrm{T}$ \\
\hline$r p m$ & $\min$ & $g-c m$ & ${ }^{\circ} \mathrm{F}$ & $g-\mathrm{cm}$ & ${ }^{\circ} \mathrm{F}$ & $g-c m$ & ${ }^{\circ} \mathrm{F}$ & $g-\mathrm{cm}$ & ${ }^{\circ} \mathrm{F}$ \\
\hline $\begin{array}{l}10 \\
10\end{array}$ & $\begin{array}{c}1 \\
10\end{array}$ & 10 & $\begin{array}{l}0 \\
0\end{array}$ & $\begin{array}{l}4 \\
4\end{array}$ & $\begin{array}{l}10 \\
10\end{array}$ & $\begin{array}{l}86 \\
86\end{array}$ & $\begin{array}{l}1 \\
1\end{array}$ & $\begin{array}{l}10 \\
10\end{array}$ & \\
\hline 100 & 1 & 11 & 0 & 3 & 10 & 212 & 1 & 8 & \\
\hline 100 & 10 & 10 & 0 & 3 & 10 & 212 & 1 & 8 & \\
\hline 500 & 1 & 21 & 0 & 126 & 10 & 244 & 1 & 13 & \\
\hline 500 & 10 & 21 & 0 & 122 & 11 & 226 & 1 & 13 & \\
\hline 1,000 & 1 & 35 & 0 & 217 & 12 & 253 & 1 & 21 & \\
\hline 1,000 & 10 & 35 & 0 & 208 & 12 & 240 & 1 & 21 & \\
\hline 2,000 & 1 & 72 & 0 & 29 & 12 & 230 & 1 & 37 & \\
\hline 2,000 & 10 & 67 & 1 & 221 & 13 & 212 & 3 & 37 & \\
\hline 4,900 & 1 & 149 & 2 & 452 & 16 & 248 & 4 & 145 & \\
\hline 4900 & 10 & 136 & 5 & 352 & 23 & 235 & 9 & 126 & \\
\hline 8,500 & 1 & 95 & 5 & 18 & 25 & 122 & 9 & 81 & \\
\hline 8,500 & 10 & 81 & 7 & 158 & 25 & 122 & 10 & 68 & \\
\hline
\end{tabular}

NotE: Oil in bearing and felt; at start $=2.77 \mathrm{~g}$; at end of testing $=2.40 \mathrm{~g}$. 
However, there was some loss of oil by bleeding from the greases in the friction testing; adherence of grease to the side plates at the end of the tests made it impractical to estimate the loss from the greased bearings. Also, in the high-temperature endurance tests there was excessive loss of grease from the bearings at the start of each test, evidenced by grease on the torque arms and smoking from the heaters.

With data taken from tables 5 and 7 , the effect of speed on frictional torque and bearing temperature rise at $-75^{\circ} \mathrm{F}\left(-59.4^{\circ} \mathrm{C}\right)$ is shown in figure 4 , on logarithmic scales. At the lower and the higher speeds the torque with the grease is about 10 times greater than with the oil, but at intermediate speeds it is only about 4 times greater than with the oil. Under the conditions of these tests (see tables 4 to 7 ), at $-75^{\circ} \mathrm{F}$ ambient temperature with forced air circulation and $8,500 \mathrm{rpm}$, it is of interest to note that the torque in gram-centimeters is approximately 10 times the temperature rise in ${ }^{\circ} \mathrm{F}$.

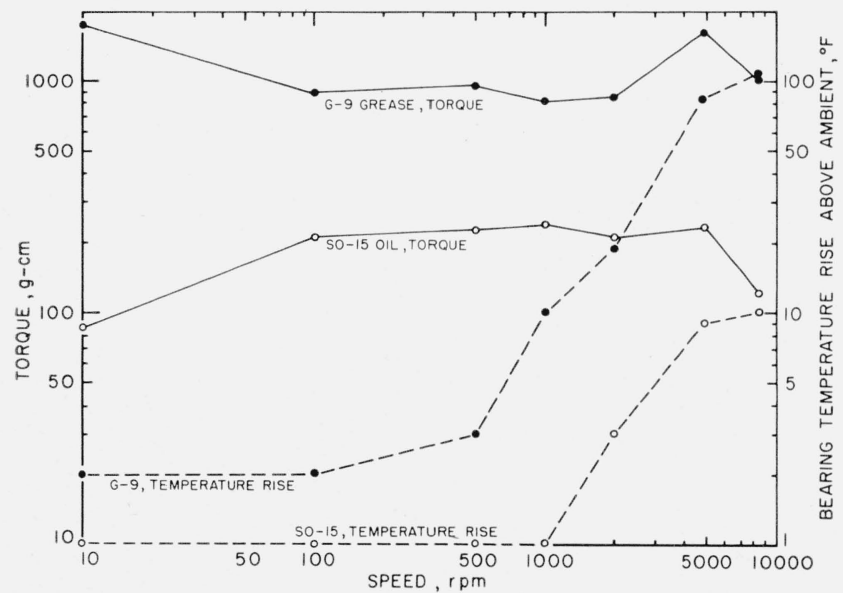

Figure 4. Effect of speed on frictional torque and bearing temperature rise at $-75^{\circ} \mathrm{F}$ ambient temperature, with $20-\mathrm{mm}$ bore ball bearings.

With size $204 \mathrm{~K}$ ball bearings freshly packed with $3.0 \mathrm{~g}$ of grease $\mathrm{G}-8$ and grease $\mathrm{G}-9$, and an extra wide $204 \mathrm{~K}$ bearing freshly oiled with $\mathrm{SO}-15$ oil in the same manner as described for the data in table 7 , data were obtained with operation at $10,000 \mathrm{rpm}$ in an ambient temperature of $-75^{\circ} \mathrm{F}\left(-59.4^{\circ} \mathrm{C}\right)$ with forced air circulation. A $1 / 2-h p$, capacitortype, 3,450-rpm, motor was connected to the spindle (behind the cold box) through a vee belt. In each test, the bearing was cooled to $-75^{\circ} \mathrm{F}$ before starting the motor. With grease G-8 the motor "hummed and groaned" but started without stopping from overloading of the built-in overload protector. With grease G-9 the overload protector stopped the motor 10 times during attempted starts even with manual help applied to the pulley, but got up to nearly normal speed on the 11th start. With the SO-15 oil the motor started with no difficulty. After starting, each run was continued for $2 \mathrm{hr}$. With the greases the torque immediately after starting was beyond the capacity of the torque measuring apparatus with the large brass weight on the bob (beyond 2,850 g-cm). The torque data for grease $\mathrm{G}-9$ and oil $\mathrm{SO}-15$ are given in figure 5 .

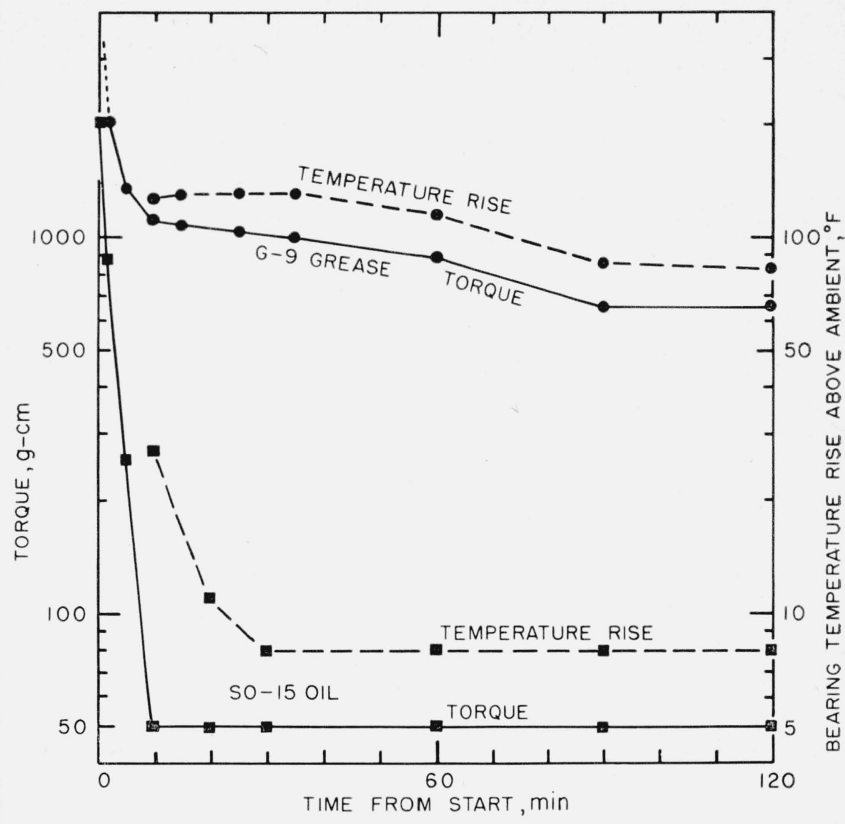

Figure 5. Effect of time on frictional torque and bearing temperature rise, at $-75^{\circ} \mathrm{F}$ ambient temperature for a $M I L-$ G-3278-type grease and $\mathrm{SO}-15$ oil, with $20-\mathrm{mm}$ bore ball bearings, at 10,000 rpm.

The temperature rise data for each bearing (not including data for the very rapid rise occurring during the first few minutes) are given also in figure 5. After $2 \mathrm{hr}$ of operation the torque with grease G-9 was about 13 times greater than the torque with oil SO-15. Except for starting with less difficulty, the torque with grease $\mathrm{G}-8$ was similar to that for $\mathrm{G}-9$ during the first hour, at $90 \mathrm{~min}$ it varied from 353 to $2,270 \mathrm{~g}-\mathrm{cm}$, and at the end of $2 \mathrm{hr}$ it was $1,010 \mathrm{~g}-\mathrm{cm}$.

Torque and temperature rise data were obtained in a similar manner at $10,000 \mathrm{rpm}$ with greases $\mathrm{G}-11, \mathrm{G}-12, \mathrm{G}-14 \mathrm{a}$, and $\mathrm{G}-15$. These data for G-11 and G-12 (ASTM greases used in ASTM study of slow-speed torque at $-65^{\circ} \mathrm{F}$ ) and for G-14a a commercial low-temperature silicone grease) are given in figure 6 . The data obtained with sample $\mathrm{G}-15$ (MIL-G-7421) were very similar to the curves given for $\mathrm{G}-11$. After $2 \mathrm{hr}$ of operation at $10,000 \mathrm{rpm}$ for greases $\mathrm{G}-8, \mathrm{G}-9, \mathrm{G}-11, \mathrm{G}-12$, and $\mathrm{G}-15$, at $-75^{\circ} \mathrm{F}$ ambient temperature the values of torque were in the range from 630 to $1,010 \mathrm{~g}-\mathrm{cm}$; but with grease $\mathrm{G}-14 \mathrm{a}$ the torque of 63 g-cm was nearly as low as the $50 \mathrm{~g}-\mathrm{cm}$ obtained with $\mathrm{SO}-15$ oil under these conditions (see fig. 5).

With grease $\mathrm{G}-13$ the bearing could not be turned by hand at $-75^{\circ} \mathrm{F}$ without bending the torque arm, and at $-50^{\circ} \mathrm{F}$ the $1 / 2$-hp motor could not start because of the high friction. The motor started the bearing at $-10^{\circ} \mathrm{F}$ and during the first $20 \mathrm{~min}$ the torque at $-10^{\circ} \mathrm{F}$ ambient temperature was similar to that for sample G-12 at $-75^{\circ} \mathrm{F}$ ambient (in fig. 6), at $10,000 \mathrm{rpm}$; but after an hour of operation the torque dropped to $88 \mathrm{~g}-\mathrm{cm}$. After standing overnight, the bearing started easily at $-10^{\circ} \mathrm{F}$ and during the next half-hour of operation the torque varied in the range from 88 to $252 \mathrm{~g}-\mathrm{cm}$. 


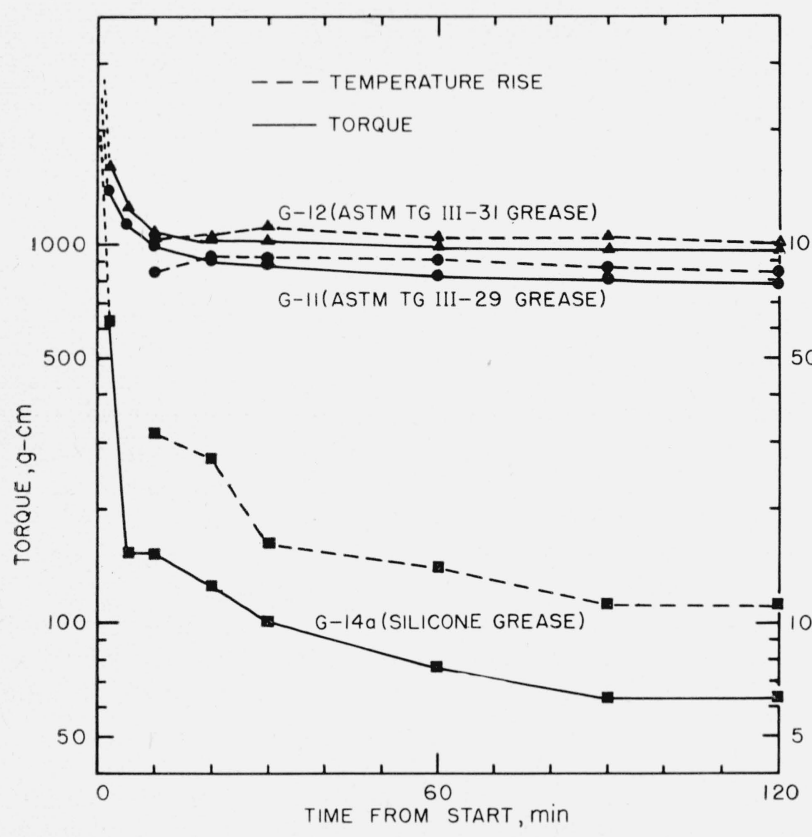

FIGURE 6. Effect of time on frictional torque and bearing temperature rise, at $-75^{\circ} F$ ambient temperature for 2 ASTM greases and a silicone grease, with $20-\mathrm{mm}$ bore ball bearings, at 10,000 rpm.

In connection with investigating the effect of the sulfurizing treatment of the M-2 high-speed tool steel bearings, frictional data were obtained with two unlubricated sulfurized bearings and with untreated dry bearings made of M-2 steel and 52100-type steel. These data were obtained in the manner described for the data in tables 4 to 7 , at room ambient temperature. The friction data for these unlubricated bearings are given in table 8 , which includes some data from tables 4 and 7 for lubricated bearings for comparison. At speeds up to $1,000 \mathrm{rpm}$ with this low load $(4 \mathrm{lb})$ the friction with the sulfurized bearing is higher than with the greased bearing and much higher than with the oiled bearing and the dry untreated bearing.

Examination with a 10-power stereomicroscope indicated that the surfaces of the sulfurized balls and races were rougher than the untreated balls and races, and this probably accounts for the relatively high friction. This is in agreement with the paragraph under table III of U.S. Patent No. 2,707,159, covering sulfurizing processes. In table 4 , the bearing which gave excessive torque after $8 \mathrm{~min}$ at $4,900 \mathrm{rpm}$ had been sulfurized before assembly of the balls and separator. The other sulfurized bearing was treated after it had been assembled.

\subsection{Miscellaneous Tests and Results a. Air-Driven Gyro Tests}

Tests were made with the modified air-driven gyro, with 10 -in. $\mathrm{Hg}$ air pressure, in an oven at controlled temperatures, with filtered air going through a coil of copper tubing for preheating the air. Tests with an air-driven gyro at high temperatures are more severe than with an electric motor, because of the greater evaporation and oxidation of the lubricant,
TABLE 8. Frictional torque for 20-mm bore ball bearings, with 4-lb radial load, $80^{\circ} \mathrm{F}$ nominal ambient temperature

\begin{tabular}{|c|c|c|c|c|c|c|c|c|}
\hline \multirow{3}{*}{ Speed } & \multirow{3}{*}{$\begin{array}{l}\text { Time } \\
\text { at each } \\
\text { speed }\end{array}$} & \multicolumn{7}{|c|}{ Torque, g-cm } \\
\hline & & \multicolumn{4}{|c|}{ 52100-type steel bearings } & \multicolumn{3}{|c|}{ M-2 tool steel bearings } \\
\hline & & $\begin{array}{l}\text { Syn- } \\
\text { thetic } \\
\text { oil }\end{array}$ & $\begin{array}{c}\text { MIL-G- } \\
3278 \\
\text { Greose }\end{array}$ & \multicolumn{2}{|c|}{ Dry } & Dry & \multicolumn{2}{|c|}{ Dry, sulfurized } \\
\hline${ }_{10}^{r p m}$ & $\min$ & & & & & & & \\
\hline $10 \ldots$ & $\begin{array}{l}1 \\
10\end{array}$ & $\begin{array}{l}10 \\
10\end{array}$ & $\begin{array}{l}99 \\
45\end{array}$ & $\begin{array}{l}12 \\
12\end{array}$ & $\begin{array}{l}16 \\
16\end{array}$ & $\begin{array}{l}12 \\
12\end{array}$ & $\begin{array}{l}32 \\
32\end{array}$ & $\begin{array}{l}32 \\
32\end{array}$ \\
\hline $100 \ldots$ & 1 & 11 & 72 & 12 & 16 & 14 & 40 & 48 \\
\hline $100 \ldots \ldots$ & 10 & 10 & 29 & 12 & 16 & 16 & 48 & 56 \\
\hline $\begin{array}{l}500 \ldots \\
500 \ldots\end{array}$ & $\begin{array}{r}1 \\
10\end{array}$ & $\begin{array}{l}21 \\
21\end{array}$ & $\begin{array}{l}48 \\
32\end{array}$ & 10 & $\begin{array}{l}16 \\
16\end{array}$ & $\begin{array}{l}16 \\
16\end{array}$ & 54 & 59 \\
\hline $1,000 \ldots$ & 1 & 35 & 64 & 12 & 21 & 18 & 68 & 68 \\
\hline $1,000 \ldots$ & 10 & 35 & 48 & 12 & 32 & 27 & 72 & 68 \\
\hline $2,000 \ldots$ & 1 & 72 & 90 & 18 & 45 & 32 & 90 & 101 \\
\hline $2,000_{\ldots} \ldots$ & 10 & 67 & 90 & 18 & 504 & 36 & 99 & 101 \\
\hline $\begin{array}{l}4,900 \ldots \\
4,900 \ldots\end{array}$ & 1 & 149 & 378 & 36 & (n) & $\begin{array}{r}90 \\
250\end{array}$ & 202 & 252 \\
\hline 4,900 & 10 & 136 & 328 & 36 & & 252 & 227 & (b) \\
\hline 8,500 & 1 & 95 & 504 & 68 & & 378 & 302 & -- \\
\hline 8,500 & 10 & 81 & 227 & (a) & & 428 & 353 & - . \\
\hline $\begin{array}{l}10,000 \ldots \\
10,000\end{array}$ & 1 & 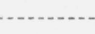 & 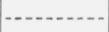 & $\ldots$ & . & 504 & 378 & - \\
\hline 10,000 & 10 & & & & & 630 & 504 & -. \\
\hline
\end{tabular}

a Seized in $7 \mathrm{~min}$, severely scuffed, broke torque arm.

b Very high torque in $8 \mathrm{~min}$; no scuffing observed, bent torque arm.

resulting from the large volume of hot air blown past the bearings. In this gyro, the shaft is fixed and the bearing outer races rotate with the rotor. An aluminum alloy cage was made such that it enclosed a felt pad wrapped around the shaft, and two small holes at each end of the cage allowed oil to bleed to the inner races of the bearings. Tests were made with 22-hr runs and shutdown periods as described for the tests on the endurance testing machines. Polyester felt pads were used, saturated with about $1.0 \mathrm{~g}$ of oil. In one test the alloy cage was omitted and the felt was fitted inside the brass sleeve used for spacing the outer ball races and hence rotated with the rotor.

The data for the tests with the air-driven gyro are summarized in table 9. At $250^{\circ} \mathrm{F}$ the endurance

TABLE 9. Ball bearing endurance tests in air-driven gyro, 20,000 rpm nominal speed, 5-mm bore

\begin{tabular}{|c|c|c|c|c|}
\hline $\begin{array}{c}\text { Ambient } \\
\text { tempera- } \\
\text { ture }\end{array}$ & Lubricant & Bearing & Separator material & $\begin{array}{l}\text { Hours run } \\
\text { before } \\
\text { failure }\end{array}$ \\
\hline$\circ F$ & & & & \\
\hline 250 & G-9. & $\mathrm{S} 34-5-\mathrm{SS}$ & Stainless steel_ & 220 \\
\hline 250 & SO- 15 & $\mathrm{~S} 34-5-\mathrm{SS}_{-}$ & Stainless steel & 22 \\
\hline 250 & SO-15 & N.D. 5 & Chrome-plated brass. & 23 \\
\hline 250 & SO- 15 & N.D. 5 & Chrome-plated brass & 94 \\
\hline 250 & $\mathrm{SO}-$ & N.D. 5 & Teflon-coated brass & 20 \\
\hline 250 & $\mathrm{SO}-15$ & N.D. & No. 220 filled Teflon a & 22 \\
\hline 250 & $\mathrm{SO}-15$ & N.D. 5 & No. 206 filled Teflon ${ }^{a}$.. & 110 \\
\hline 250 & $\mathrm{SO}-15 \ldots$ & N.D. 5 & 10 balls filled raceway & 66 \\
\hline 250 & & $34-5 \mathrm{~B}$ & Phenolic composition & 378 \\
\hline 250 & & $34-5 \mathrm{~B}$ & Phenolic composition & b 307 \\
\hline 250 & $\mathrm{SO}$ & N.D. 5 & Teflon-coated brass & 7 \\
\hline 325 & $\mathrm{SO}^{-}$ & N.D. 5 & Teflon. & 22 \\
\hline 325 & SO- 16 & N.D. 5 & No. 206 filled Teflon a & 22 \\
\hline 325 & $\mathrm{SO}-17$ & N.D. 5 & Asbestos-phenolic & 22 \\
\hline 325 & $\mathrm{SO}-17 \ldots$ & $34-5 \mathrm{~B}$ & Phenolic composition & 33 \\
\hline
\end{tabular}

a See reference [8] for descriptions of No. 206 and No. 220 filled Teflon.

b The oil-soaked felt was installed in the rotating brass sleeve used for spacing the outer ball races instead of in the stationary alloy cage used in the other tests. 
$(378 \mathrm{hr})$ with the commercial phenolic composition separator was much better than with any of the other separator materials in the oil-prelubricated bearings. With the stainless steel separators the endurance with grease G-9 (220 hr) was much better than with $\mathrm{SO}-15$ oil $(22 \mathrm{hr})$. In the 4 tests at $325^{\circ} \mathrm{F}$, the endurances (33 hr maximum.) were very short with the lubricants and separators that were tried.

\section{b. Small Direct-Current Motor Tests}

Endurance tests were made with bearings in the 27-v, d-c, 11,000-rpm motors. Three tests were made with motors having their shafts connected to shafts of other motors modified to act as generators, with a resistor connected to the generator lead wires adjusted to load the driving motors to a nominal speed of $11,000 \mathrm{rpm}$. During the tests each motorgenerator unit was installed in an aluminum box, 6 in. by 6 in. by 12 in., with a transite base and a clear plastic front, to simulate installation in a closed compartment. No heat was provided except that from the test units, and no provision was made for controlling the temperature. After warm-up during the first hour of each $22-\mathrm{hr}$ period of operation, in general the air temperature inside the box ranged from $150^{\circ}$ to $200^{\circ} \mathrm{F}$ and the temperature inside the motor case ranged from $200^{\circ}$ to $250^{\circ} \mathrm{F}$. Failure to restart or continue running with a 5-amp fuse in the circuit was used as a criterion for a bearing failure; ordinarily, the motors started and continued running with a 3-amp fuse.

In test DCMG-1, the original SS77034 bearings as received, prelubricated with $\mathrm{G}-14$ silicone grease, were tested in a motor-generator unit in the box. After $245 \mathrm{hr}$ of operation the bearing at the brush end of the generator failed by seizure.

In test DCMG-2, one of the metal shields was removed from each of the SS77034 bearings and the bearings were cleaned with solvents. The motors were modified slightly at each end to accommodate aluminum alloy cups containing oil-soaked polyester felt pads. SO-15 oil was used in the felts and bearings. After $61 \mathrm{hr}$ of operation the bearing at the brush end of the generator failed because of excessive wear of the separator.

In test DCMG-3, operation of the motor used in test DCMG-2 was continued. The generator was fitted with new Q34 ball bearings having phenolic-fabric separators, with $\mathrm{SO}-15$ oil in the felts and bearings. After $780 \mathrm{hr}$ (including $61 \mathrm{hr}$ in previous test) the SS77034 bearing at the brush end of the motor failed because of a worn and broken steel separator. The Q34 bearings in the generator with $719 \mathrm{hr}$ of operation did not fail, although under similar conditions the SS77034 bearing with the steel separator at the brush end of the generator failed in $61 \mathrm{hr}$.

Five tests were made with the $27-v$, d-c, 11,000rpm motors under no load conditions, at a nominal speed of $16,000 \mathrm{rpm}$. The motors were operated in the enclosed box described for the motor-generator tests.
In test DCM-1 with the original SS77034 bearings as received, prelubricated with $\mathrm{G}-14$ silicone grease, the bearing at the shaft (output) end failed by seizure after $84 \mathrm{hr}$ of operation.

In test DCM-2, a motor was fitted with Q34 bearings having phenolic-fabric separators, with $\mathrm{SO}-15$ oil in the felts and bearings. The bearings did not seize, but inspection at $2,237 \mathrm{hr}$ of operation disclosed excessive wear of the separators.

In test DCM-3 with the original SS77034 bearings as received, prelubricated with $\mathrm{G}-14$ silicone grease, the bearing at the shaft end failed and caused stoppage because of very high friction after $173 \mathrm{hr}$ of operation.

In test DCM-4, as received (same as in tests DCM-1 and DCM-3), the bearing at the shaft end caused stoppage after $264 \mathrm{hr}$ of operation.

In test DCM-5, Q34 bearings were fitted and lubricated as in test DCM-2. They were inspected after $1,743 \mathrm{hr}$ of operation. The separators were worn and the test was discontinued, but probably operation could have been continued to a total of $2,000 \mathrm{hr}$.

In these tests with d-c motors, the operation was interrupted frequently because of difficulties other than bearing failure. These difficulties included brush wear, brushes sticking in holders, brush "pigtail" wire stiffness preventing brush movement to compensate for wear, breaking of "pigtail" wires, and melting of solder joints.

Starting tests were made with the $27-\mathrm{v}$, d-c motors in a low-temperature cabinet, at $-76^{\circ} \mathrm{F}\left(-60^{\circ} \mathrm{C}\right)$, after storage for $18 \mathrm{hr}$ and again after storage for $42 \mathrm{hr}$.

With a motor as received, factory prelubricated with G-14 silicone grease, there was no difficulty in starting at $-76^{\circ} \mathrm{F}$ with a 3 -amp fuse.

With the motor used in test DCM-2, prelubricated with SO-15 oil, after $500 \mathrm{hr}$ of operation (in test DCM-2), there was no difficulty in starting at $-76^{\circ} \mathrm{F}$ with a 3 -amp fuse.

A motor freshly prelubricated with SO-15 oil (later used in test DCM-5) would not start after $18 \mathrm{hr}$ at $-76^{\circ} \mathrm{F}$ with a 3 -amp fuse, but started with a 5-amp fuse. After 24 more $\mathrm{hr}$ (42 $\mathrm{hr}$ total) at $-76^{\circ} \mathrm{F}$ the motor started with a 3 -amp fuse. However, after running $3 \mathrm{hr}$ at room temperature, the results of a test after $18 \mathrm{hr}$ at $-76^{\circ} \mathrm{F}$ were the same as before the 3 -hr run-in at room temperature.

\section{Service Test in $1 / 2$-hp Motor}

Size 202KTT bearings fitted with polyester felt rings, prelubricated with $\mathrm{SO}-15$ oil, were installed in a $1 / 2-\mathrm{hp}, 3,450-\mathrm{rpm}$ motor used for driving one of the endurance testing machines. These bearings were functioning normally after $4,200 \mathrm{hr}$ of operation at the conclusion of the project.

\section{Conclusions}

Polyester felt pads saturated with SO-15 oil (see table 1 for composition) may be incorporated in prelubricated ball bearings to provide satisfactory operation in the temperature range from $-75^{\circ}$ to 
$+325^{\circ} \mathrm{F}$, with type $204 \mathrm{KT} T$ bearings and probably with bearings having bores ranging from 10 to $35 \mathrm{~mm}$. Endurance with bearings prelubricated in the above manner is comparable with the high-temperature performance of MIL-G-3278 [1] grease at $250^{\circ} \mathrm{F}$ and MIL-L-3545 [2] grease at $300^{\circ} \mathrm{F}$. Compared to MIL-G-3278 and MIL-G-7421 [3] greases, with the oiled bearings starting friction is low and running friction is about one-tenth of that of greased bearings.

Although it is not feasible to incorporate oiled felt pads in small instrument bearings (less than 10-mm bore) of conventional width, oiled pads may be installed in instruments (or motors) to provide oil prelubrication for the bearings.

Although Teflon felt may be used for ambient temperatures up to $450^{\circ} \mathrm{F}$ and glass felt mav be used for much higher temperatures, none of the high temperature oils were satisfactory for prelubrication at $450^{\circ} \mathrm{F}$ ambient temperature.

Excessive wear occurred with unlubricated highspeed tool steel bearings when operated at 5,000 rpm in a $650^{\circ} \mathrm{F}$ ambient temperature, but operation with these unlubricated bearings could be satisfactory for very short periods in special applications.

The major cause of failure in endurance tests with the bearings prelubricated with oil-soaked felt pads was breakage or wear of the separators. Improvements in separators could greatly increase the endurance life of oil-prelubricated ball bearings.

The modified air-driven gyro may be useful for evaluating lubricants for high-speed instrument ball bearings at high temperatures. It is being tried by other laboratories for this purpose in connection with efforts of the Coordinating Research Council to develop a test method for instrument-bearing lubricants. Advantages are the ease of detection of bearing failure (indicated by stoppage or reduced speed) and the absence of other components which may fail, especially at high temperatures. The high air velocity increases the evaporation and oxidation of the lubricant. While this shortens the test, the air environment is not typical of enclosed ball bearings in most service applications.

Low-temperature torques of ball bearing greases determined for starting and running at $1 \mathrm{rpm}$ as in ASTM Tentative Method D1478-57'T are not significant in predicting the starting and running torques at $10,000 \mathrm{rpm}$ at $-75^{\circ} \mathrm{F}$ ambient temperature. This conclusion is based, partly on data for the ASTM greases TG-III-29 and TG-III-31; from other laboratories the torque with TG-III-31 was nearly four times greater than with TG-III-29 by the ASTM method, but in figure 6 the torque data for these greases soon after starting at 10,000 rpm do not differ greatly. Also, data [9] from another laboratory show no correlation between results of torque tests by the ASTM method and the results of tests on actual aircraft accessory equipment.

The author is grateful for information and/or material samples received from the following:

The Fafnir Bearing Company

Bendix Aviation Corp. (Eclipse-Pioneer Div.)

E. I. duPont de Nemours and Company

Lehigh Chemical Company

Western Felt Works

Lubri-Case, Incorporated

The Drever Company

Continental-Diamond Fibre Corporation

Hooker Electrochemical Co. (Durez Plastics Div.)

General Electric Company

American Felt Company

Kearfott Company, Inc.

Industrial Tectonies, Ine.

Coordinating Research Council

Wright Air Development Center

U.S. Naval Engineering Experiment Station

Naval Research Laboratory

\section{References}

[1] MIL-G-3278 Military Specification: Grease; aircraft and instruments (for low and high temperatures).

[2] MIL-L-3545 Military Specification: Lubricating grease; high temperature.

[3] MIL-G-7421 Military Specification: Grease; extreme low temperature.

[4] H. S. White, J. F. Swindells, and H. V. Belcher, Oilsoaked felt-pad lubrication of ball bearings at high speed and high temperature, Lubrication Eng. 11, 182 (1955).

[5] MIL-L-7808 Military Specification: Lubricating, gas turbine, aircraft.

[6] 14L3c Navy Specification: Grease, ball and roller bearing (superseded by MIL-G-18709).

[7] MIL-G-25C13 Military Specification: Grease, ball, and roller bearing, extreme high temperature.

[8] H. S. White, Small oil-free bearings, J. Research NBS 57, 185 (1956) RP2709.

[9] E. A. Baniak and R. S. Barnett, (Beacon Laboratories, The Texas Company), Low-temperature operation of aircraft accessories, presented at ASLE meeting, April 1955 .

Washington, D.C.

(Paper 63C1-2) 